\title{
MOLECULAR PHYLOGENETIC ANALYSIS OF THE NORTH-TEMPERATE LABRADOR TEAS (ERICACEAE: RHODODENDRON SUBSECT. LEDUM) SUGGESTS A COMPLEX GENETIC HISTORY
}

\author{
Andrew Hart \\ Department of Biological Sciences \\ Marshall University \\ One John Marshall Drive \\ Huntington, West Virginia 25705, U.S.A. \\ hart78@live.marshall.edu
}

\section{Kathleen Kron}

\author{
Department of Biology \\ Wake Forest University \\ 1832 Wake Forest Road \\ Winston-Salem, North Carolina 27109, U.S.A. \\ kronka@wfu.edu
}

\author{
Emily Gillespie \\ Department of Biological Sciences \\ Marshall University \\ One John Marshall Drive \\ Huntington, West Virginia 25705, U.S.A. \\ gillespieE@marshall.edu
}

\begin{abstract}
The Labrador teas are a group of nearly circumboreal shrubs or sub-shrubs inhabiting damp habitats. The 4-7 currently recognized species are classified within Rhododendron subg. Rhododendron section Rhododendron subsect. Ledum. In floral characters, these species are extremely similar. In vegetative characters, species limits in the Labrador teas have been difficult to determine because many of the traditionally used morphological characters vary continually across the geographic range. This study investigated evolutionary history and preliminary consideration of some species boundaries in the Labrador teas using DNA sequence data from five molecular markers to generate a preliminary phylogeny of R. subsect. Ledum. Data were analyzed using Maximum Parsimony, Maximum Likelihood and Bayesian methods. The nuclear data indicate a monophyletic subsect. Ledum, but chloroplast data indicate that the North American taxa have an evolutionary history separate from the European and Asian taxa, suggesting that one or both lineages of subsect. Ledum may be of hybrid origin. Additionally, our analyses suggest that taxa combined in recent treatments (i.e. Rhododendron tomentosum) represent separate lineages and should be recognized as distinct instead of included within more broadly defined species, however our current level of sampling cannot completely resolve this issue. This study lays the groundwork for future phylogenetic studies within subsect. Ledum, illustrating the need to sample more intensively across taxa in order to capture what appears to be a complex genetic and biogeographic history.
\end{abstract}

Key Words: Biogeography, Ericaceae, Hybridization, Labrador Tea, Ledum, Molecular phylogenetics, Rhododendron

\section{RESUMEN}

Los tés del Labrador son un grupo de arbustos o subarbustos casi circumboreales que viven en hábitats húmedos. Las 4-7 especies reconocidas normalmente se clasifican en Rhododendron subg. Rhododendron sección Rhododendron subsect. Ledum. En los caracteres florales, estas especies son muy similares. En los caracteres vegetativos, los límites de las especies de los tés del Labrador han sido difíciles de establecer porque muchos de los caracteres morfológicos usados tradicionalmente varían continuamente a lo ancho de su rango geográfico. En este estudio se investigó la historia evolutiva y las consideraciones preliminares de las fronteras de especies en los tés del Labrador usando datos de secuencias de ADN de cinco marcadores moleculares para generar una fiologenia preliminar de R. subsect. Ledum. Los datos se analizaron usando Máxima Parsimonia, Máxima Verosimilitud y métodos Bayesianos. Los datos nucleares indican una subsect. Ledum monofilética, pero los datos cloroplásticos indican que los taxa norteamericanos tienen una historia evolutiva separada de los taxa europeos y asiáticos, sugiriendo que uno o ambos linajes de la subsect. Ledum pueden ser de origen híbrido. Adicionalmente, nuestros análisis sugieren que taxa combinados en tratamientos recientes (ej. Rhododendron tomentosum) representan linajes separados y deben ser reconocidos como distintos en vez de ser incluidos en especies definidas más ampliamente, sin embargo, con nuestro nivel actual de muestreo no se puede resolver completamente este asunto. Este estudio pone las bases para futuros estudios filogenéticos en la subsect. Ledum, mostrando la necesidad de muestrear más intensivamente los taxa para capturar lo que parece ser una historia compleja genética y biogeográfica.

\section{INTRODUCTION}

The Labrador Teas (Rhododendron subsect. Ledum) are a small group of evergreen shrubs and sub-shrubs with an intermittently circumboreal distribution that are often dominant in damp ecosystems such as peat bogs, 
muskegs, and acidic, sandy loams (Voss 2011). Labrador tea has been used in traditional herbal medicine (e.g., Dampc \& Luczkiewicz 2013; Collin 2015; Dampc \& Luczkiewicz 2015), with biological activity supported by a few pharmacological studies (reviewed in Popescu \& Kopp 2013).

Historically, Labrador tea was recognized as the genus Ledum L. (tribe Rhodoreae) (Stevens 1971) due to the unusual presence of choripetalous flowers, multicellular trichomes and glands, and the absence of viscin threads in the pollen, all unlike Rhododendron s.s. (Copeland 1943). In their cladistic analysis of the tribe Rhodoreae, Kron and Judd (1990) included Ledum within Rhododendron based primarily on the shared characters of unique multicellular, glandular, peltate scales. Additionally, developmental studies (Leins 1964) demonstrated that the corolla of Ledum species is actually sympetalous.

Three related issues have made the species-level taxonomy of the Labrador teas complex. First, morphological cladistic analyses of the tribe Rhodoreae suggested that Rhododendron was paraphyletic if Ledum was separately recognized and these results prompted Kron and Judd (1990) to include Ledum within the genus Rhododendron as Rhododendron subg. Rhododendron sect. Rhododendron subsect. Ledum. Molecular phylogenetic studies have continued to support the inclusion of Ledum within Rhododendron (Kron 1997; Kurashige et al. 2001; Goetsch et al. 2005) but Labrador teas are still frequently listed in some floras (e.g. Flora Europaea and Flora of China) and by amateur botanists under the name "Ledum". Kron and Judd (1990) made new combinations for two species of Labrador tea (R. palustre (L.) Kron \& Judd; R. groenlandicum (Oeder) Kron \& Judd), but did not at that time include new combinations for other Labrador tea species. In response, additional new combinations were subsequently made by Harmaja (1990, 1991, 1999, 2002), but the process of transferring all Ledum to Rhododendron took a decade. Second, simple nomenclatural transfer to Rhododendron was not possible in some cases due to existing use of epithets within Rhododendron. For example, Rhododendron macrophyllum is an existing accepted name, and so Ledum macrophyllum Tolm. was renamed Rhododendron tolmachevii Harmaja. Third, major floras treat this small group quite differently. For example, the recent treatment of Rhododendron in the Flora of North America (FNA) (Judd \& Kron 2009) combined several taxa due to their morphological similarity and the absence of reasonably clear morphological gaps with which to recognize species boundaries. Specifically, Rhododendron neoglandulosum Harmaja was included within Rhododendron columbianum (Piper) Harmaja and Rhododendron palustre L., Rhododendron subarcticum Harmaja, Rhododendron subulatum (Nakai) Harmaja (Harmaja 2002), Rhododendron tolmachevii Harmaja, and Rhododendron diversipilosum (Nakai) Harmaja were all included within R. tomentosum Harmaja. Only the circumscription of Rhododendron groenlandicum (Oeder) Kron \& Judd was left unmodified in FNA. Because FNA focuses on North American taxa, this approach may obscure how variation on other continents is recognized if one relies on this manual when examining species that occur on continents other than North America, such as R. tomentosum. In contrast, the Flora of China (FoC) (Ruizhang \& Chamberlain 2005) includes a single species, Ledum palustre, whose four recognized subspecies have been considered to be three separate species by Harmaja (R. subulatum, R. subarcticum and R. tomentosum) but all combined within R. tomentosum in FNA. Flora Europaea (Tutin et al. 1972) recognizes Ledum groenlandicum and several subspecies of L. palustre; like FoC, Flora Europaea does not include Ledum within Rhododendron. These numerous nomenclatural changes in a relatively short period of time and markedly different handling by commonly used floras, in combination with being found in remote locations resulting in likely incomplete distributional information, make this small group of arctic plants challenging to study phylogenetically.

The current study provides a preliminary species-level molecular phylogeny of Rhododendron subsect. Ledum using five markers from both the nucleus and chloroplast. This phylogeny represents a necessary starting point for future fine-scale investigations of species boundaries and historical biogeography by providing strong evidence of a reticulate evolutionary history as well as identifying non-monophyletic taxa that have been combined taxonomically (e.g., Rhododendron tomentosum), which should be investigated by using less inclusive taxonomic/biological entities in future efforts. This study also provides a basis for future biogeographic studies of north temperate Asia, Europe and North America. 
METHODS

Taxon sampling.-Included exemplars/species, voucher information and Genbank numbers are reported in Table 1. Ingroup taxa were sampled following Harmaja (1991, 1999, 2002), who recognizes more species than are in FNA (Judd \& Kron 2009). Rhododendron columbianum (Piper) Harmaja and Rhododendron neoglandulosum Harmaja were both included and these are together recognized in FNA (Judd \& Kron 2009) as Rhododendron columbianum (Piper) Harmaja. Rhododendron groenlandicum (Oeder) Kron \& Judd was included and is also recognized in FNA. Rhododendron diversipilosum (Nakai) Harmaja, Rhododendron hypoleucum (Kom.) Harmaja, Rhododendron tolmachevii Harmaja, and Rhododendron tomentosum Harmaja s.s. were included and all four of these taxa are together recognized in FNA (Judd \& Kron 2009) as Rhododendron tomentosum Harmaja. Additionally, Rhododendron palustre L. was included from Siberia following FoC (Ruizhang \& Chamberlain 2005). Rhododendron subulatum (Nakai) Harmaja and Rhododendron subarcticum Harmaja were not sampled due to inadequate tissue for DNA extraction. Rhododendron subulatum is considered likely morphologically indistinguishable from Rhododendron palustre in FoC (Ruizhang \& Chamberlain 2005) and R. subarcticum is considered to be synonymous with R. tomentosum s.l. in FNA, but these two taxonomic problems each require further clarification.

Previous studies (Kron \& Judd 1990; Kurashige et al. 1998) have placed subsect. Ledum as a clade within the lepidote lineage Rhododendron subg. Rhododendron L. (Cullen 1980). Therefore, outgroup sampling included representatives from five additional Rhododendron species from this subgenus, including Rhododendron baileyi Balf.f., Rhododendron afghanicum Aitch. \& Hemsl., Rhododendron sargentianum Rehder \& E.H. Wilson, Rhododendron orbiculatum Ridley and Rhododendron hippophaeoides Balf. f. \& Sm. Five elepidote Rhododendron subgenera (following Goetsch et al. 2005) were represented by Rhododendron quinquefolium Bisset \& Moore (subg. Azaleastrum Planch.), Rhododendron albiflorum Hook. (subg. Candidastrum Franch.), Rhododendron arborescens (Pursh) Torr. (subg. Pentanthera (G. Don) Pojarkova), Rhododendron grande Wight (subg. Hymenanthes (Blume) K. Koch) and Rhododendron camtschaticum (Pall.) Sm. (subg. Therorhodion (Maxim.) A. Gray). Two closely related non-Rhododendron tribes were represented by Ceratiola ericoides Michx. (tribe Empetreae Horan.) and Calluna vulgaris (L.) Hull (tribe Ericeae DC. ex Duby). Cassiope mertensiana G. Don was included to represent the Cassiopoideae H.T. Cox ex P.F. Stevens, the most closely related subfamily to Ericoideae (Kron \& Chase 1993; Kron 1997; Kron et al. 2002; Gillespie \& Kron 2010).

Molecular methods.-Total DNA was extracted from fresh samples, herbarium specimens or silicadried material using a modified cetyltrimethyl ammonium bromide (CTAB) protocol (Doyle \& Doyle 1987) or the DNeasy Plant Mini Kit (Qiagen, Valencia CA, USA) with modifications following Drábková et al. (2002).

Chloroplast regions $3^{\prime} \operatorname{trn} \mathrm{V}^{(\mathrm{UAC})}-n d h \mathrm{C}$, $\operatorname{trn} \mathrm{S}^{(\mathrm{GCU})}-\operatorname{trn}^{(\mathrm{UUC})}$ (both from the Large Single Copy region),

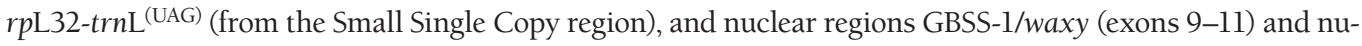
clear ribosomal Internal Transcribed Spacer (nrITS) were utilized. Chloroplast regions were selected based on their predicted utility as described in Shaw et al. (2007) and amplified using Shaw's recommended primers and PCR parameters. The low-copy nuclear gene GBSS-1/waxy (exons 9-11) (Evans et al. 2000) and nrITS (Baldwin 1992) have each been shown to be valuable for low-level taxonomic studies despite potential complications associated with nrITS, addressed below. Primer selection and PCR amplification of nrITS and waxy followed Gillespie and Kron (2010). Qiagen ${ }^{\mathrm{TM}}$ QIAquick Gel Isolation Kit was used to isolate amplified fragments (Qiagen, Valencia CA, USA).

Concerns have been raised in recent years (e.g., Álvarez \& Wendel 2003; Poczai \& Hyvönen 2010) about the phylogenetic utility of nrITS in plant phylogenetic studies, primarily because of the possibility of amplifying paralogous sequences. Although careful use of this region is clearly warranted, nrITS is well-understood and represents a useful source of nuclear DNA data in Rhododendron. Here, a combined strategy of spot-cloning (five randomly-chosen clones per taxon, for at least one taxon per subgenus) and vigilant examination of chromatogram data was used to minimize the likelihood of employing paralogous sequences. Specifically, nrITS sequences were examined 'blind' (i.e. individually, outside the context of a data matrix) as well as within the context of the complete data matrix, so that chromatograms at particularly variable regions could be 


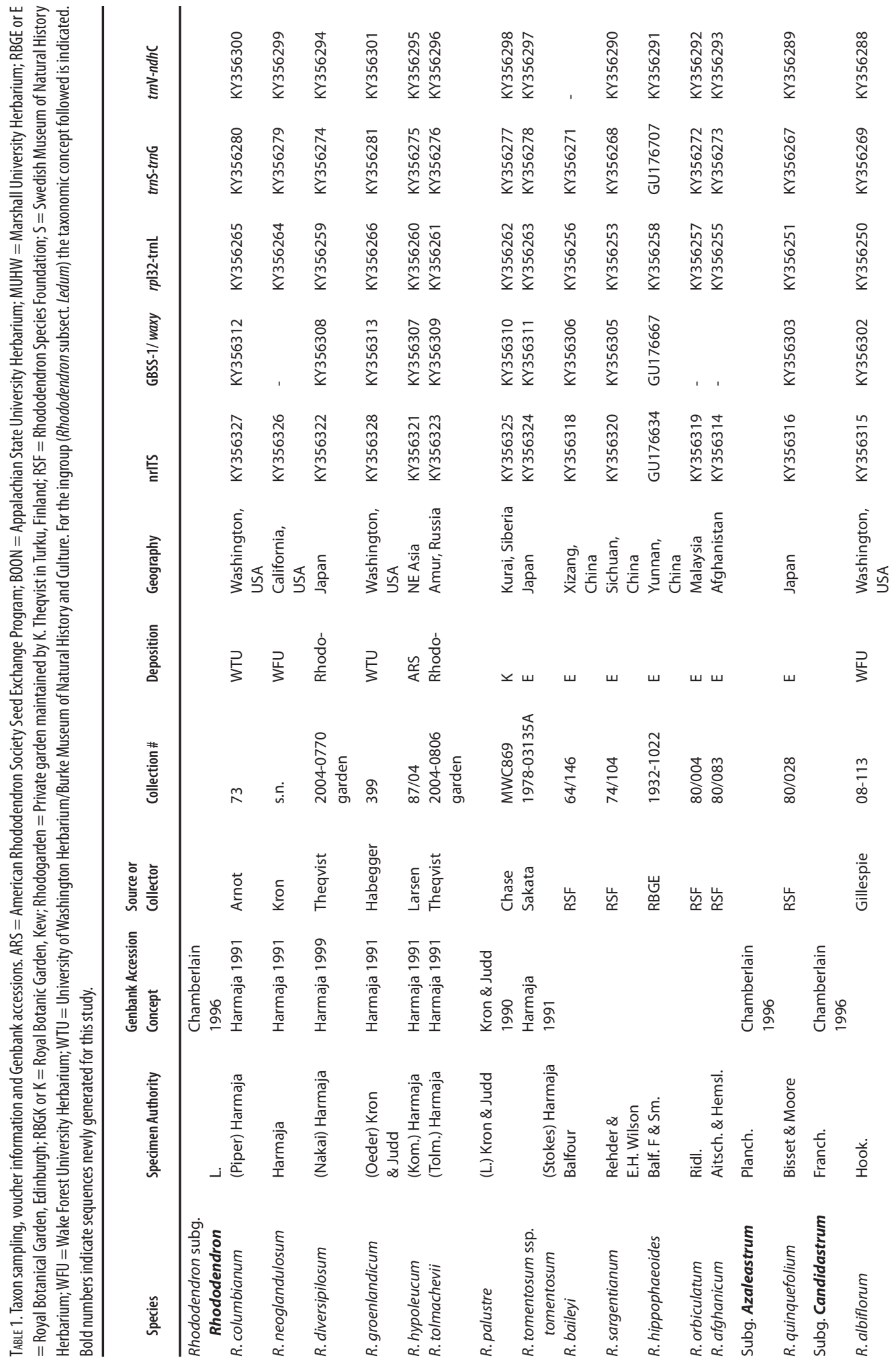




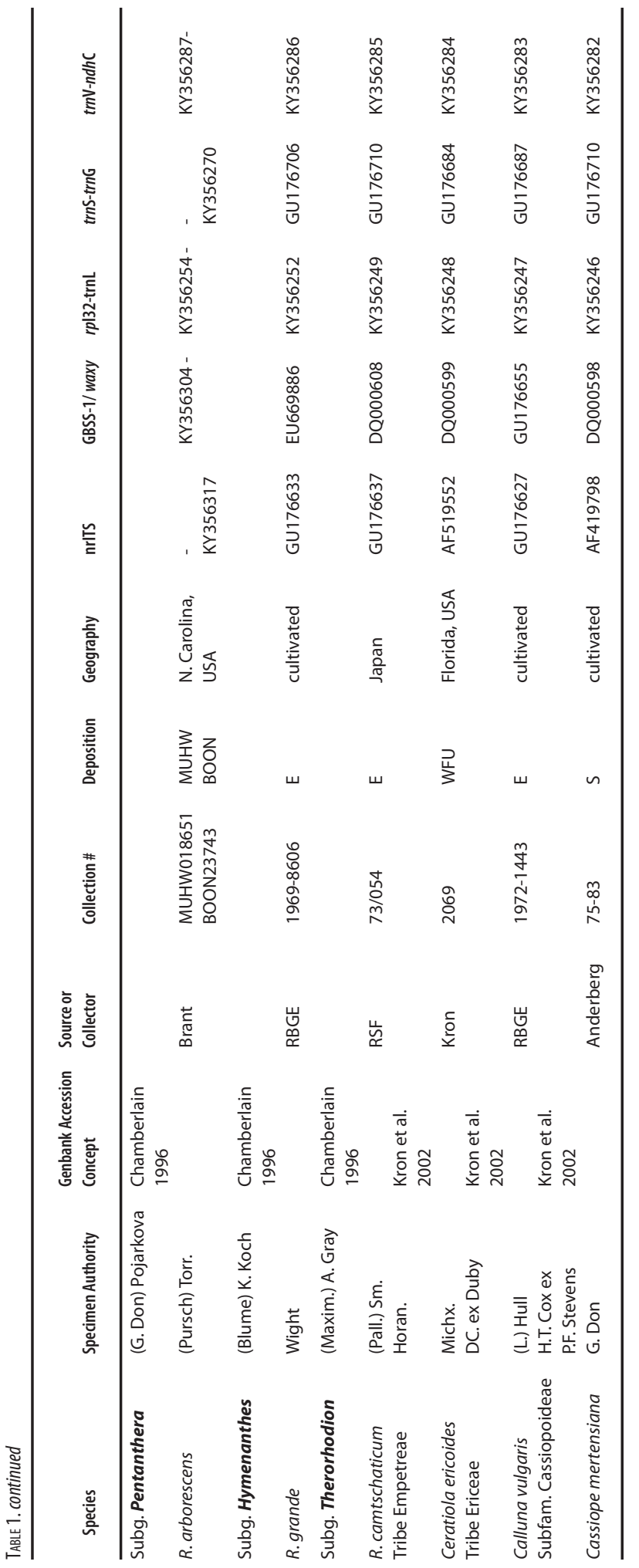


specifically examined for evidence of multiple amplicons. No evidence of paralogs for nrITS or waxy/GBSS-1 was discovered for this study. Gel-isolated amplicons or cloned plasmids were sequenced at the Nevada Genomics Center (Reno, NV, USA) or at Eton Biosciences (Raleigh, NC, USA).

Geneious versions 8.1 through 9.1.4 (Biomatters, Ltd.) (http://www.geneious.com; Kearse et al. 2012) were used in the storage and curation, manual alignment, and minimal editing of DNA sequences. Any ambiguous base calls were checked against the chromatogram and conservatively edited. Bases at each end of the raw sequence with more than a 5\% probability of base-call error or peak quality lower than Q20 were trimmed and excluded.

Phylogenetic analyses.-Maximum Parsimony (MP) analyses were conducted on separate matrices of combined nuclear data and combined chloroplast data using PAUP*4.0a147, Jan. 2016 release (Swofford 2003) with the following parameters: Phylogenetically uninformative (i.e., non-variable or autapomorphic) characters were excluded, informative characters were equally weighted and unordered, gaps were treated as missing data, and multiple independent heuristic searches were conducted with TBR branch swapping and 1000 random stepwise addition replicates. Clade support was evaluated using bootstrap analysis (Felsenstein 1985; Felsenstein 1988) with 10,000 replicates. Cassiope mertensiana was identified as the outgroup taxon.

Maximum Likelihood (ML) analyses were carried out using the online RAxML tool (Stamatakis et al. 2014) through the Cipres Web Portal (http://www.phylo.org/sub_sections/portal/). Matrices of combined nuclear and combined chloroplast data were analyzed, with datasets partitioned as separate DNA regions under the GAMMA model recommended for smaller sample sizes, with Cassiope mertensiana identified as the outgroup taxon.

Bayesian analyses were run based on models tested for individual markers within jModelTest 2.1.3 (Guindon \& Gascuel 2003; Darriba et al. 2012) using the corrected Aikake Information Criterion (AICc) which corrects for small sample size (fewer than approximately 40 terminals). Bayesian MCMC analysis (Yang $\&$ Rannala 1997) was conducted on combined, partitioned nuclear and chloroplast data as implemented in Mr. Bayes version 3.2.6 × 86 (Huelsenbeck \& Ronquist 2001; Ronquist \& Huelsenbeck 2003). Analyses consisted of 50,000,000 generations with a burn-in of $25 \%$ of the tree set and a split deviation of $<0.01$.

The Incongruence Length Difference (ILD) test (Farris et al. 1995), implemented as the Partition Homogeneity Test in PAUP*4.al47 (Swofford 2003), was conducted to determine whether nuclear and chloroplast data recovered sufficiently congruent phylogenies to be combined into a total molecular evidence analysis. A heuristic search with 1000 replicates was performed using TBR branch swapping and simple, stepwise addition of taxa.

RESULTS

The aligned length, best fitting evolutionary model according to jModeltest, and amount of missing data (number of taxa and percent of taxa) for each partition are reported in Table 2. For chloroplast and nuclear data, branch support values are presented in the following format: Bayesian posterior probability / ML bootstrap / MP bootstrap. Bootstrap values (MP or ML) below 50\% and Bayesian posteriors below 0.90 are shown as dashes (-) and are considered here to be essentially non-existent branch support. Data matrices for individual markers, combined nuclear and chloroplast matrices and both nuclear and chloroplast phylogenies are deposited in TreeBASE (TreeBASE.org) under number S19409.

Nuclear data (Fig. 1).-Analyses of combined nuclear data (nrITS and waxy exons 9-11 strongly support (0.99/87 / 77) a monophyletic subsect. Ledum (hereafter 'Ledum clade'). This clade plus the remaining lepidote taxa sampled (R. afghanicum, R. baileyi, R. hippophaeoides, R. orbiculatum, and R. sargentianum) form a wellsupported clade $(0.97 / 90 / 72)$ and these two clades are sister to each other $(1.00 / 98 / 96)$.

Within the Ledum clade, R. groenlandicum is sister to R. hypoleucum (1.00/95/79) and these two taxa are moderately to weakly supported as sister to $R$. tomentosum $(0.91 / 65 / 51)$. Rhododendron columbianum $+R$. tolmachevii (-/73/63) are together resolved as sister to R. groenlandicum $+R$. hypoleucum $+R$. tomentosum, but with fairly weak support in ML and MP only $(-/ 65 / 57)$. These five taxa are sister the $R$. diversipilosum $+R$. 
TABLE 2. Marker, aligned length (in base pairs), best-fitting evolutionary model, and number of missing taxa (and \%). * indicates that a single taxon has an incomplete sequence.

\begin{tabular}{|c|c|c|c|}
\hline Marker & Aligned Length (bp) & Model (AICC) & \# Missing taxa (\%) \\
\hline nrITS & 617 & TPM1uf $+\mathrm{G}$ & 0 \\
\hline GBSS-1/waxy & 570 & $\mathrm{HKY}+\mathrm{G}$ & $3(14.2 \%)^{*}$ \\
\hline $\operatorname{trn} S^{(G C U)}-\operatorname{trn} G^{(U U C)}$ & 1374 & TVM+G & 0 \\
\hline$r p \mathrm{~L} 32-\operatorname{trn}^{(\mathrm{UAG})}$ & 848 & TVM+G & 0 \\
\hline $3^{\prime} \operatorname{trn} \mathrm{V}^{(\mathrm{UAC})}-n d h \mathrm{C}$ & 490 & $\mathrm{HKY}+\mathrm{G}$ & $1(4.7 \%)$ \\
\hline
\end{tabular}

palustre clade (0.92 / 48/57) but again with weak support from only ML and MP analyses (-/69/64). The inset phylogram showing branch lengths was generated from the same Bayesian topology as the cladogram and the terminals are in the same order.

Chloroplast data (Fig. 2). - In contrast to the nuclear results, analyses of the combined chloroplast data $\left(t r n S^{(G C U)}-t r n G^{(\mathrm{UUC})}, r p \mathrm{~L} 32-\operatorname{trn}^{(\mathrm{UAG})}\right.$, and 3'trn $\left.\mathrm{V}^{(\mathrm{UAC})}-n d h \mathrm{C}\right)$ indicate that $R$. subsect. Ledum is not monophyletic. Rhododendron diversipilosum, R. hypoleucum, R. palustre, R. tolmachevii and R. tomentosum, are resolved as a clade with very strong support $(1.00 / 100 / 99)$. This clade of $R$. subsect. Ledum is sister to R. sargentianum + $R$. baileyi $(0.94$ / 78 / 58) with Bayesian posterior support $(0.90 /$ - / 50). The other three $R$. subsect. Ledum representatives ( $R$. groenlandicum, $R$. neoglandulosum, $R$. columbianum) are resolved as a clade with very strong support (1.00/100/100), and they are nested within a clade of other sampled lepidote Rhododendron including R. orbiculatum, R. afghanicum and R. hippophaeoides with moderate to strong support (0.91 / 86/ 66). This clade of six lepidote Rhododendron are sister to R. albiflorum (0.94/ 78 / 76) and then R. quinquefolium (1.00/99/87). All of these species form a clade along with R. arborescens (subg. Pentanthera) and R. grande (subg. Hymenanthes) with strong support (1.00/100/99). Finally, R. camtschaticum (subg. Therorhodion) is strongly supported (1.00/98/98) as sister to all other Rhododendron.

In addition to numerous single-nucleotide indels, two longer sections of DNA in the chloroplast data support the close relationship of the North American subsect. Ledum species (R. columbianum, R. groenlandicum and R. neoglandulosum) to Rhododendron species outside subsect. Ledum rather than to the Asian subsect. Ledum species ( $R$. diversipilosum, $R$. tomentosum, R. hypoleucum, R. tolmachevii and R. palustre). In the trnS (GCU) $\operatorname{trn} \mathrm{G}^{(\mathrm{UUC})}$ intergenic spacer, bases 506-514 of (5'-AATTCCTAA-3') is a likely insertion in the Asian subsect. Ledum species that is absent in all other taxa sampled, including the three North America subsect. Ledum

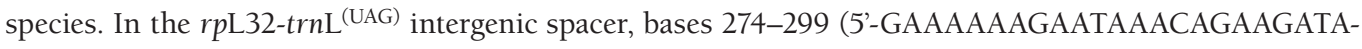
CAA-3') is found in the North American subsect. Ledum taxa and in R. orbiculatum, R. hippophaeoides, R. albiflorum and R. quinquefolium, all of which form a strongly supported clade (1.00/99/87). Most other Rhododendron taxa, including the Asian subsect. Ledum taxa, have the sequence 5'-TGTATCTTCTGTTTATTCTTTTTTC-3' in the same position.

The ILD test indicated that the nuclear and chloroplast data partitions were in conflict $(p=0.01)$ and should not be combined for total evidence analyses. Valid questions about the relevance of the ILD test in phylogenetics have been raised (e.g, Cunningham 1997; Yoder et al. 2001; Barker \& Lutzoni 2002), due in part to the likelihood of making a Type I error (i.e., failing to combine the datasets when they are not truly incongruent-i.e. a 'soft' polytomy), or disagreement about the most appropriate p-value for this test (Cunningham 1997). In the current study, however, the conflicting nodes in the nuclear versus chloroplast analyses are very strongly supported. Analyses of combined total data (i.e., nuclear + chloroplast) resulted in a nearly complete loss of resolution and support in the region of the conflicts and are therefore not informative (and not shown).

DISCUSSION

This study is the first to use molecular data to address the evolutionary history of Rhododendron subsect. Ledum, a small group of geographically widespread, yet morphologically similar species. The number of taxa in 

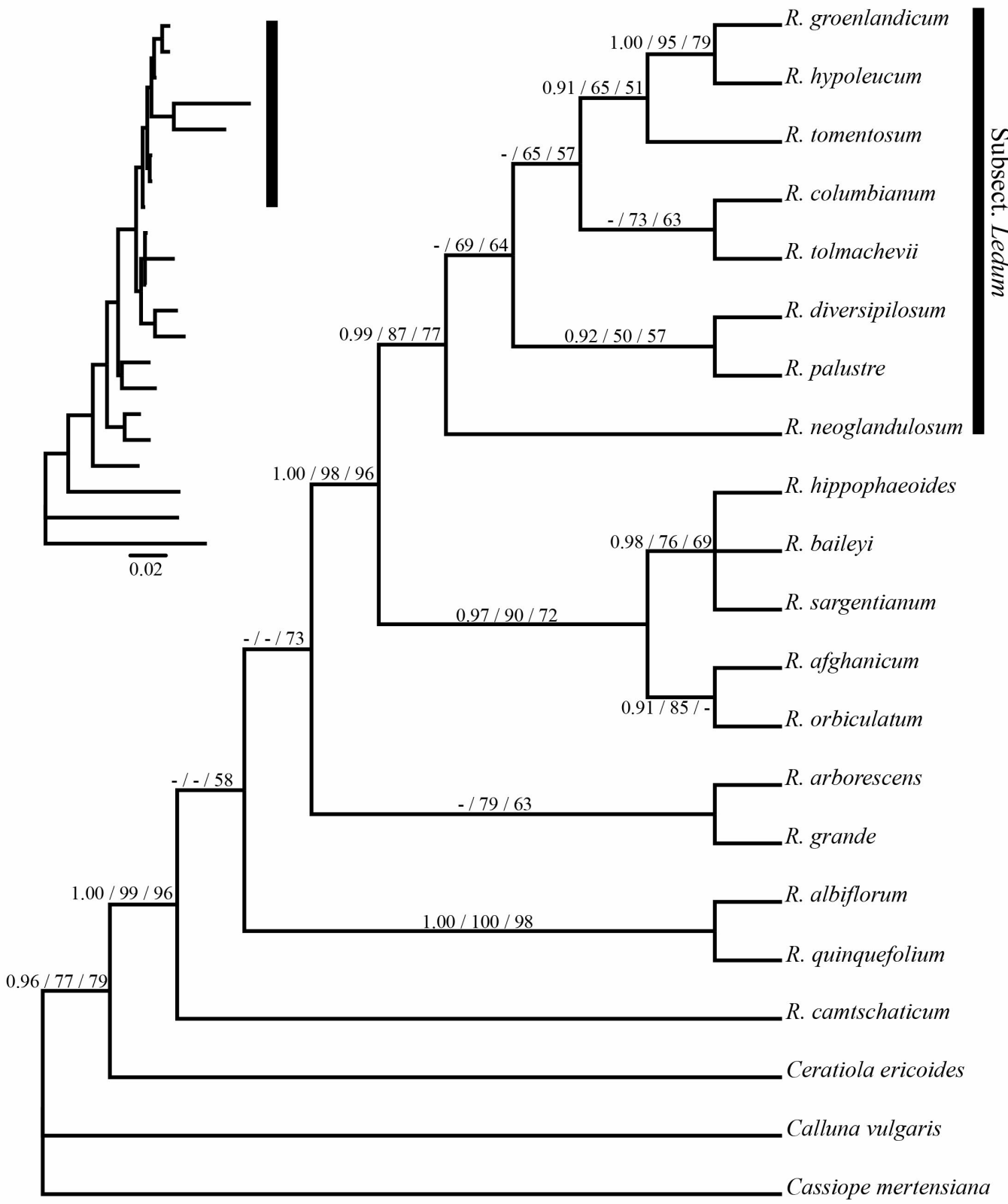

\section{COMBINED NUCLEAR DATA}

FIG. 1. Total combined nuclear data (nrITS and exons 9-11 of GBSS-1/waxy). Support values are to the left of nodes in the format (Bayesian posterior probability/ML bootstrap/MP bootstrap). Support derived from 50 million Bayesian MCMC generations, 100 ML bootstrap replicates and 10,000 MP bootstrap replicates. Parsimony tree length $=225, \mathrm{Cl}=0.6533, \mathrm{RI}=0.6977$. $\mathrm{RAxML}$ Likelihood score $=-4603.601284$. Black bar indicates $R$ hododendron subsect. Ledum. The Bayesian topology is shown for both the cladogram and the inset phylogram. 


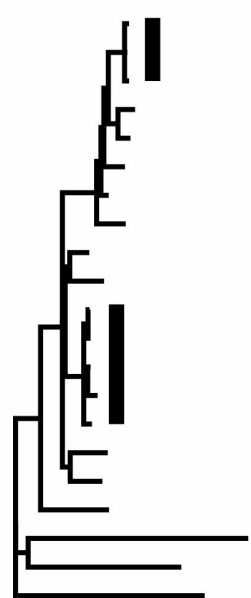

$0 . \overline{00} 6$

R. groenlandicum columbianum

R. neoglandulosum

R. orbiculatum

R. afghanicum

R. hippophaeoides

R. albiflorum

R. quinquefolium

R. sargentianum

R. baileyi

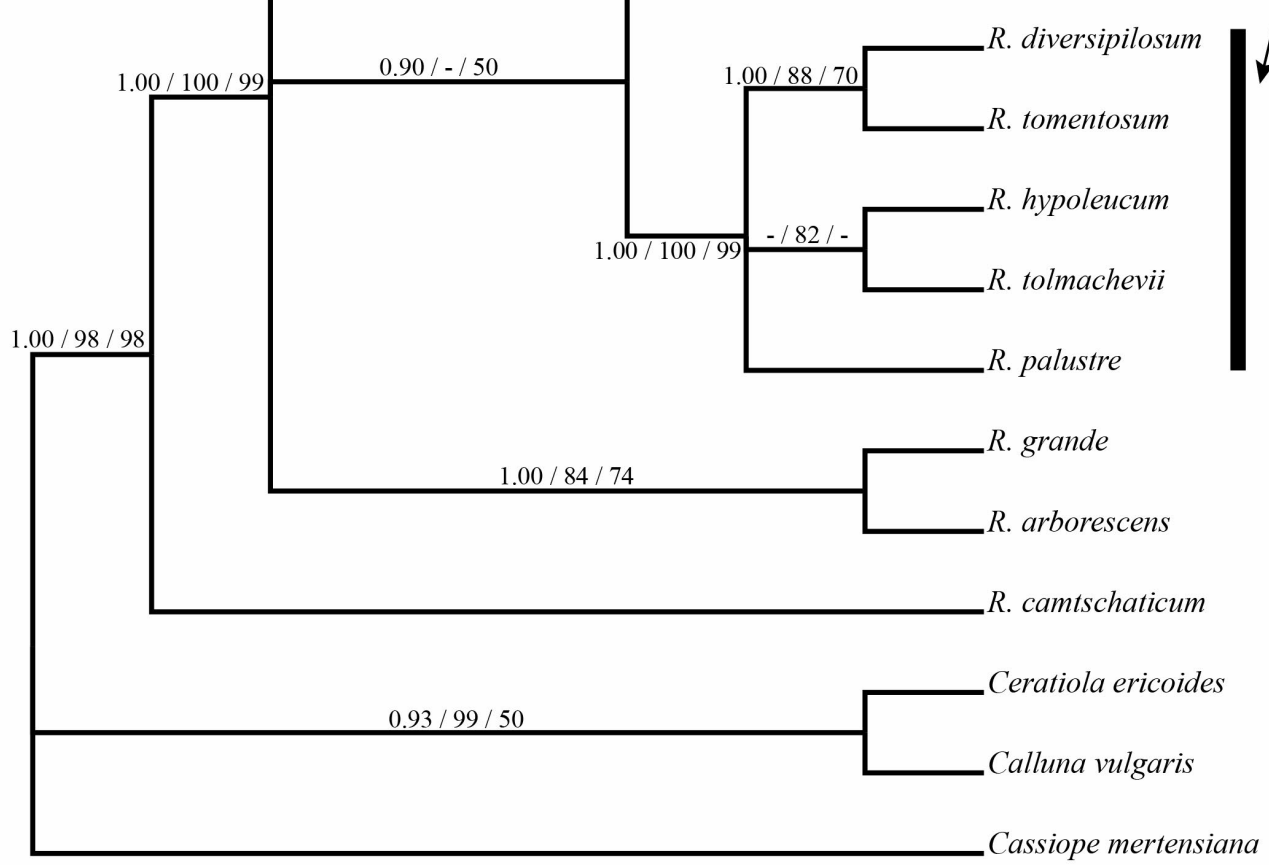

COMBINED CHLOROPLAST DATA

FIG. 2. Total combined chloroplast data (trnS $S^{(G C U)}-\operatorname{trnG}^{(\mathrm{UUC})}, r p L 32-\operatorname{trnL}^{(\mathrm{UAG})}$ and $3^{\prime} \operatorname{trn} \mathrm{V}^{(\mathrm{UAC})}$-ndhC). Support values are to the left of nodes in the format (Bayesian posterior probability/ML bootstrap/MP bootstrap). Support derived from 50 million Bayesian MCMC generations, $100 \mathrm{ML}$ bootstrap replicates and 10,000 MP bootstrap replicates. Parsimony tree length $=223, \mathrm{Cl}=0.6278, \mathrm{RI}=0.7629$. RAxML Likelihood score $=-6863.805129$. Black bar indicates Rhododendron subsect. Ledum. The Bayesian topology is shown for both the cladogram and the inset phylogram. 
this lineage has been the subject of debate and the phylogeny we present here is a necessary first step to addressing finer-scale questions in the future, especially questions related to species boundaries and genome evolution.

Overall, analyses of combined nuclear and combined chloroplast data yield very good resolution and support despite limited sampling outside subsect. Ledum relative to the size and diversity of the Rhododendron lineage ( $\sim 1,000$ species). The most prominent finding here is that information from the nuclear and chloroplast genomes of $R$. subsect. Ledum do not indicate the same evolutionary history. The nuclear data strongly indicate a monophyletic $R$. subsect. Ledum that is sister to a clade containing lepidote species from other subgroups within the genus, but the combined chloroplast data strongly indicate that the primarily North American taxa, R. groenlandicum, R. columbianum and R. neoglandulosum, are more closely related to species of Rhododendron from other subsections than to the other members of $R$. subsect. Ledum. A total of 35 potentially parsimonyinformative (PPI) characters in the chloroplast genome (26.1\% of the total number of PPI characters) support the conclusion that the North American $R$. subsect. Ledum taxa are more closely related to other subsections than to other taxa of $R$. subsect. Ledum. This result may suggest that these taxa are of hybrid origin with egg parents from other subsections within the R. subg. Rhododendron, specifically subsect. Afghanica (represented here by R. afghanicum), subsect. Lapponicum (represented by R. hippophaeoides) or from subg. Vireya (represented by R. orbiculatum). The Asian subsect. Ledum taxa may be more closely related to section Anthopogon (represented here by R. sargentianum) or to subsect. Baileya (represented here by R. baileyi). These results permit an alternate hypothesis, that it is the Asian subsect. Ledum taxa which are of hybrid origin, their ancestor having acquired its chloroplast genome from a species of subsect. Baileya or sect. Anthopogon. Still a third scenario is possible, where both subsect. Ledum clades are of hybrid origin with maternal parents from different lepidote lineages. The current study included representatives of six Rhododendron subgenera and three subsections within subg. Rhododendron in addition to subsect. Ledum. However, in such a large genus as Rhododendron, this sampling is not sufficient to further address the question of parentage and was beyond the scope of this initial attempt to reconstruct the evolutionary history of subsect. Ledum. In order to clarify which subsect. Ledum clade is of hybrid origin (or potentially, both clades), future sampling must include representatives of most if not all of the 29 currently recognized subsections of Rhododendron subg. Rhododendron. Many lepidote Rhododendron species are geographically near by or even overlapping with subsect. Ledum.

Some insights into the biogeographic history of subsect. Ledum are possible from the current results. Not all nodes are strongly supported, but several are, and these allow formation of biogeographical hypotheses that can be addressed in future studies with additional sampling. Nuclear data strongly suggest that $R$. groenlandicum (widespread in northern North America and present in Europe) is most closely related to R. tomentosum and R. hypoleucum (from Japan and Norway, respectively). Other nodes within the nuclear data are not wellsupported, including nodes that place the other North American taxa (R. columbianum and R. neoglandulosum). Chloroplast data unambiguously place $R$. groenlandicum in a clade with $R$. columbianum and $R$. neoglandulosum (both from the Pacific Northwest of North America). Since the three North American taxa are most closely related to R. orbiculatum and R. afghanicum, this may suggest that the ancestor of these three taxa acquired its chloroplast genome from a lepidote ancestor related to these two species of Rhododendron. This further suggests that this hybridization event was coincident with migration into North America from Europe or Asia. The direction of migration cannot currently be resolved with confidence, but a picture is beginning to emerge. Matthews (1979) proposed that a belt of arctic biome existed in the northern hemisphere by approximately three million years ago, providing new niches for ancestors inhabiting mountain chains farther south (e g. Hultén, 1937) to migrate into, during glacial minima. Certainly the center of diversity of Rhododendron supports this scenario, with many species occurring in and around the Himalayas. Taken together, this information may suggest that during the last three million years, an ancestor of the modern-day North American subsect. Ledum species acquired a chloroplast genome from a mountain-inhabiting lepidote Rhododendron, possibly in the Himalayas, and migrated across Beringia into North America where speciation occurred, generating a widespread taxon (R. groenlandicum) and two more narrowly distributed taxa (R. columbianum and R. neoglandulo- 
sum). In Asia, differentiation into extremely similar forms (R. tomentosum s.l.) with or without hybridization has occurred during the same period of time. These species are all very closely related, as illustrated by their branch lengths and the ability to form artificial hybrids (Kihlman 2004), but the Eurasian group and the North American group may be on fairly separate evolutionary trajectories at this time.

The ploidy level of all subsect. Ledum taxa have not yet been determined, but Lantai \& Kihlman (1995) examined two formerly recognized Ledum taxa, L. palustre L. and L. palustre L. ssp. decumbens (Ait.) Hultén, both currently included within Rhododendron tomentosum Harmaja in FNA (Judd \& Kron 2009). Lantai and Kihlman found that L. palustre s.s. from Sweden was a polyploid $(2 n=52)$ but that $L$. palustre ssp. decumbens was diploid $(2 n=26)$. The current study included an accession of R. tomentosum (= L. palustre) from Siberia and found no evidence of polyploidy in the chromatograms. Kristian Theqvist (unpubl. data) has found using flow cytometry that $R$. diversipilosum, $R$. groenlandicum and $R$. hypoleucum are likely polyploids. Our study determined that $R$. groenlandicum is possibly of hybrid origin and therefore possibly an allopolyploid, however investigation of chromatograms revealed no evidence of paralogs in any DNA marker used in this study. In the current study, R. diversipilosum and R. hypoleucum were placed unambiguously within the 'tomentosum' subclade using chloroplast data and with all subsect. Ledum taxa in the nuclear data, exhibiting no phylogenetic behavior generally consistent with a hybrid origin. Additionally, no evidence of hybridization was discovered in the chromatograms of these two species. These results may illustrate that the phylogenetic behavior of polyploids is unpredictable in phylogenetic analyses, or perhaps a hybridization event occurred recently enough that more intensive sampling would be required to reveal such behavior. An additional or alternative interpretation is that both in the current study and in past attempts to understand ploidy levels within subsect. Ledum, sampling density has not captured the complexity of the genetic landscape. In other words, the taxonomic complexity of this group may in fact reflect the biological reality that small pockets of populations may be morphologically virtually indistinguishable but genetically divergent. Future studies should take into account the possibility that terminals representing entire species or even subspecies/varieties may not be sufficient for capturing genetic diversity, and ideally multiple terminals per biological entity should be included.

Clearly, future investigations of this group must include dense sampling across the range of most if not all currently or formally recognized species, in order to fully describe its complex genetic and biogeographic history, particularly within the context of post-glacial migration and northern hemisphere vicariance and dispersal. Specific goals should include, 1) Sampling of as many of the 29 current Rhododendron subsections as possible. This will permit clarification regarding whether one or both subsect. Ledum lineages are of hybrid origin and to specify the nearest related subsection and therefore the likely source(s) of their chloroplast genome, 2) A herbarium-based accounting of each subsect. Ledum species' distribution. Now that many herbaria are becoming digitized, it is likely that distributions of these remote taxa may be expanded beyond 'broad brush' dot maps and this may inform sampling and/or interpretation of biogeography, and 3) Extensive sampling of extant taxa across their ranges, including where overlap with other subsect. Ledum species occur. It will be important in future studies to treat this small but complex group of plants in a more fine-scale way, given the intra-species genetic structure we have presented here, in order to fully illuminate their evolutionary history.

\section{ACKNOWLEDGMENTS}

The authors wish to thank Marshall University for startup funding for Gillespie in addition to the Marshall University Yeager Scholar Program for providing funding for Hart to attending conferences and present this work. Kristian Theqvist (Finnish Rhododendron Society) provided important plant tissue. Staff at the University of Washington Herbarium (WTU) Appalachian State University herbarium (BOON) and Wake Forest University Herbarium (WFU) provided some specimens for sampling. We thank Walter Judd and one anonymous reviewer for their helpful comments and suggestions on the manuscript. 


\section{REFERENCES}

Álvarez, I. \& J.F. Wendel 2003. Ribosomal ITS sequences and plant phylogenetic inference. Molec. Phylogen. Evol. 29:417-434.

BALDWIN, B. 1992. Phylogenetic utility of the internal transcribed spacers of nuclear ribosomal DNA in plants: An example from the Compositae. Molec. Phylogen. Evol. 1:3-16.

BARKER, F. \& F. LUTZONI. 2002. The utility of the incongruence length difference test. Syst. Biol. 51:625-637.

Colıin, G. 2015. Aromas from Quebec. IV. Chemical composition of the essential oil of Ledum groenlandicum: A review. Amer. J. Essential Oils Nat. Prod. 2(3):6-11.

CopelAND, H. 1943. A study, anatomical and taxonomic of the genera of Rhododendroideae. Amer. Midl. Naturalist 30:533-625.

CuLLEN, J. 1980. A revision of Rhododendron 1. Subgenus Rhododendron Sections Rhododendron and Pogonanthum. Roy. Bot. Gard. Edinburgh 39:1-207.

Cunningham, C.W. 1997. Can three incongruence tests predict when data should be combined? Molec. Biol. Evol. 14:733-740.

DAMPC, A. \& M. LUCZKIEWICZ. 2013. Rhododendron tomentosum (Ledum palustre). A review of traditional use based on current research. Fitoterapia 85:130-143.

Dampc, A. \& M. LuCZKIEWICZ. 2015. Labrador tea-the aromatic beverage and spice: A review of origin, processing and safety. J. Sci. Food Agric. 95:1577-1583. doi:10.1002/jsfa.6889

DarRiBA, D., G.L. TABOADA, R. Doallo, \& D. PosadA. 2012. jModelTest 2: More models, new heuristics and parallel computing. Nature Meth. 9:772.

DoYLE, J. \& J. DoyLE. 1987. A rapid DNA isolation procedure for small quantities of fresh leaf tissue. Phytochem. Bull. Bot. Soc. Amer. 19:11-15.

DrÁBKOVÁ, L., J. KIRSCHNER, \& Č.VLČEK. 2002. Comparison of seven DNA extraction and amplification protocols in historical herbarium specimens in Juncaceae. PI. Molec. Biol. Reporter 20:161-175.

Evans, R.C., L.A. Alice, C.S. CAmpbeLl, E.A. KellogG, \& T.A. Dickinson. 2000. The granule-bound starch synthase (GBSSI) gene in the Rosaceae: Multiple loci and phylogenetic utility. Molec. Phylogen. Evol. 17(3):388-400.

FarRis, J., S.M. Kallersjo, A.G. KLuge, \& C. Bult. 1995. Constructing a significance test for incongruence. Syst. Biol. 44:570-572.

FELSENSTEIN, J. 1985. Confidence limits on phylogenies: An approach using the bootstrap. Evolution 39:783-791.

FELSENSTEIN, J. 1988. Phylogenies from molecular sequences: Inference and reliability. Ann. Rev. Genet. 22:521-565.

GILLESPIE, E. \& K. KRON. 2010. Molecular phylogenetic relationships and a revised classification of the subfamily Ericoideae (Ericaceae). Molec. Phylogen. Evol. 56:343-354.

GoETSCH, L.A., A.J. ECKERT, \& B. Hall. 2005. The molecular systematics of Rhododendron (Ericaceae): A phylogeny based upon RPB2 gene sequences. Syst. Bot. 30:616-626.

GuInDON, S. \& O. GASCUEL. 2003. A simple, fast and accurate method to estimate large phylogenies by maximum-likelihood. Syst. Biol. 52:696-704.

HaRMAJA, H. 1990. New names and nomenclatural combinations in Rhododendron (Ericaceae). Ann. Bot. Fenn. 27:203-204.

Harmaja, H. 1991. Taxonomic notes on Rhododendron subsection Ledum (Ledum, Ericaceae), with a key to its species. Ann. Bot. Fenn. 28:171-173.

HaRmaja, H. 1999. Rhododendron diversipilosum, comb. nov. (Ericaceae). Ann. Bot. Fenn. 35:263-264.

HaRmaja, H. 2002. Rhododendron subulatum, comb. nov. (Ericaceae). Ann. Bot. Fenn. 39:183-184.

HUELSENBECK, J. \& F. Ronquist. 2001. MrBayes: Bayesian inference of phylogenetic trees. Bioinformatics 17:754-755.

HuLTén, E. 1937. Outline of the history of arctic and boreal biota during the Quarternary period. Lehre J Cramer, New York, U.S.A.

JUDD, W.S. \& K.A. KRON. 2009. Rhododendron. In: Flora of North America Editorial Committee, eds. Flora of North America north of Mexico. Oxford University Press, New York, U.S.A., and Oxford, U.K. 8:371-372, 374-375, 451, 453, 455.

KEARSE, M. (\& 13 others). 2012. Geneious Basic: An integrated and extendable desktop software platform for the organization and analysis of sequence data. Bioinformatics 28(12):1647-1649.

KIHLMAN, B. 2004. Hybrids between Ledums and lepidote Rhododendrons. J. Amer. Rhododendron Soc. 58:74-81.

KRON, K. 1997. Phylogenetic relationships of Rhododendroideae (Ericaceae). Amer. J. Bot. 84:973-980. 
KRoN, K. \& M. CHASE. 1993. Systematics of Ericaceae, Empetraceae, Epacridaceae, and related taxa based upon rbcL sequence data. Ann. Missouri Bot. Gard. 80:735-741.

KRON, K. \& W. JUDD. 1990. Phylogenetic relationships within the Rhodoreae (Ericaceae) with specific comments on the placement of Ledum. Syst. Bot. 15:57-68.

Kron, K.A., W.S. Judd, P.F.Stevens, D.M. Crayn, A.A. Anderberg, P.A. GAdek, C.J. Quinn, \& J.L. Luteyn. 2002. Phylogenetic classification of Ericaceae: Molecular and morphological evidence. Bot. Rev. 68(3):335-423.

Kurashige, Y., J. EToH, T. HANDA, K. TAKAYAnAGI, \& T. YukaWa. 2001. Sectional relationships in the genus Rhododendron (Ericaceae): Evidence from matk and trnK intron sequences. PI. Syst. Evol. 228:1-14.

Kurashige, Y., M. Mine, N. Kobayashi, T. Handa, K. Takanayagi, \& T. Yukuwa. 1998. Investigation of sectional relationships in the genus Rhododendron (Ericaceae) based on matK sequences. J. Jap. Bot. 73:143-154.

LANTAI, K. \& B. KIHLMAN. 1995. The chromosome number of Ledum palustre ssp. decumbens and of some related taxa. Hereditas (Lund.) 122:181-184.

LEINS, P. 1964. Entwicklungsgeschichtliche Studien an Ericales Blüten. Bot. Jahrb. Syst. 83:57-88.

MATTHEWS J.V. 1979. Tertiary and Quaternary environments: Historical background for an analysis of the Canadian insect fauna. In: Canada and its insect fauna (ed. Danks HV), Entomological Society of Canada, Ottawa. Pp. 31-86.

PoczAl, P. \& J. Hrvönen. 2010. Nuclear ribosomal spacer regions in plant phylogenetics: Problems and prospects. Molec. Biol. Reporter. 37:1897-1912.

PoPESCU, R. \& B. Kopp. 2013. The genus Rhododendron: An ethnopharmacological and toxicological review. J. Ethnopharmacol. 147:42-62.

Ronquist, F. \& J. HUelSENBECK. 2003. MrBayes 3: Bayesian phylogenetic inference under mixed models. Bioinformatics 19:1572-1574.

Ruizhang, F. \& D.F. Chamberlain. 2005. Ledum. In: Wu Z.Y., P.H. Raven, \& D.Y. Hong, eds. Flora of China. (Apiaceae through Ericaceae). Science Press and Missouri Botanical Garden Press, Beijing, China, and St. Louis, Missouri, U.S.A. 14:214.

SHAW, J., E. LICKEY, E. SCHILLNG, \& R. SMALL. 2007. Comparison of whole chloroplast genome sequences to choose noncoding regions for phylogenetic studies in angiosperms: The tortoise and the hare III. Amer. J. Bot. 94:275-288.

StAMATAKIS, A. 2014. RAxML Version 8: A tool for phylogenetic analysis and post-analysis of large phylogenies. Bioinformatics 30:1312-1313. doi:10.1093/bioinformatics/btu033

SteVEns, P.F. 1971. A classification of the Ericaceae: Subfamilies and tribes. Bot. J. Linn. Soc. 64:1-53.

SWOFFORD, D.L. 2003. PAUP*: Phylogenetic analysis using parsimony (* and other methods). Version 4.0a147, January 2016 release. Sinauer Associates, Massachusetts, U.S.A.

Tutin, T.G., V.H. Heywood, N.A. Burges, D.M. Moore, D.H. Valentine, S.M. Walters, \& D.A. WebB. 1972. Flora Europaea, Volume 3 (Diapensiaceae to Myoporaceae). Cambridge Univ. Press, New York, New York, U.S.A.

Voss, D.H. 2011. A key for Ledum in Rhododendron. J. Amer. Rhododendron Soc. 65(2):99-101.

YANG, Z.\& B. RannalA. 1997. Bayesian phylogenetic inference using DNA sequences: A Markov Chain Monte Carlo method. Molec. Biol. Evol. 14:714-724.

YodER, A. D., J.A. IRWIN, \& B.A. PAYSEUR. 2001. Failure of the ILD to determine data combinability for slow loris phylogeny. Syst. Biol. 50:408-424. 